\title{
Classroom Management with Concept Cartoons
}

\author{
Ahmet Karahan, Çağda Kivanç Çağanağa \\ European University of Lefke, Lefke, Northern Cyprus \\ Email: ckivanc@eul.edu.tr, ahmetcetinkarahan@yahoo.com
}

How to cite this paper: Karahan, A. and Çağanağa, Ç.K. (2017) Classroom Management with Concept Cartoons. Open Access Library Journal, 4: e3919.

https://doi.org/10.4236/oalib.1103919

Received: August 30, 2017

Accepted: September 24, 2017

Published: September 27, 2017

Copyright (C) 2017 by authors and Open Access Library Inc.

This work is licensed under the Creative Commons Attribution International License (CC BY 4.0).

http://creativecommons.org/licenses/by/4.0/

\begin{abstract}
This research aims to decrease the misconceptions and concerns of students in mathematic lessons, increase their interest towards the lesson and bring it to the desired level through concept cartoons and help teachers manage their classrooms efficiently. A cartoon delivers an idea directly while shaking the thinking worlds of individuals. Therefore, $11^{\text {th }}$ Grade students studying in 20 Temmuz Science High School during 2015-2016 academic year were chosen. Concept cartoons were applied in mathematics lesson throughout the research. Concept cartoons were prepared for each concept concerning the lesson that would also include the students. 9 concept cartoons were developed on this issue. The application was conducted in 8 weeks. Students were interviewed after the application. A further study needs to be done in order to find out its effectiveness on learning and classroom management.
\end{abstract}

\section{Subject Areas}

Education

\section{Keywords}

Concept Cartoons, Classroom Management, Geometry

\section{Introduction}

The Turkish word for geometry is originated from géometrie in French. The French word is originated from "geodesy" in Ancient Greek. The Ancient Greek term for geometry is the combination of "location" and "measure". According to many researchers, babies encounter with various geometric shapes since the birth; their perceptions of shapes and sizes start from the early ages; the babies learn information about shapes with their mouths and hands, experience about the shapes of objects and the development of geometric thinking starts with games [1] [2] [3] [4] [5]. Since the beginning of school life, children come across with geometric shapes. Before they learn numbers, they play with geometric 
shapes. Geometry is very important in the education life of students. The deductive thinking method acquired in geometry lesson may also be used in different disciplines for the solution of problems. Through the adoption of artistic aspect of geometry, the environment is perceived and analysed better. Geometry is a daily concept encountered by individuals. The background knowledge of students about geometry determines their interest levels for the lesson. When the geometry is not delivered through a constructive method, students begin to experience misconceptions towards geometry lesson. In order to have functional and permanent learning, students should be active in the knowledge building process [6]. When teachers are aware of the background knowledge of students, their learning styles and teaching methods, the lessons can be provided in a much organic way. The classroom environment ensures an effective and efficient classroom management and the perceptions of students towards the geometry. A positive perception that would be established eliminated the potential negative behaviours. In Turkish Republic of Northern Cyprus, geometry lessons are not taught in high schools as a separate lesson. In Turkey, education is under a restructuring program, and geometry lesson will no longer be taught [7]. Intensive curriculum and lack of revisions by teachers increase the concern. Lack of geometry related tools and reluctance of teachers have a negative impact on students. The lessons are taught by traditional methods and difficulties experienced during the geometry lessons affect the classroom management for the teachers, which lead the teachers to find different teaching methods.

\section{Classroom Management}

Classroom management is the organisation of academic and administrative activities that are required for the establishment of a good learning environment for the students in the classroom and maintain the learning. Classroom management is to eliminate the obstacles interrupting the teaching in classroom, ensure that students do not have any behaviours and ideas distracting their interest and attention for the lesson, plan the teaching activities, use the time in the classroom effective and efficient, ensure student participation, select and use of appropriate classroom tools and manage the physical factors, resources, relations and people [8] [9] [10] [11].

Effective classroom management:

Based on the individual and psychological needs of students;

Establishment of a good student-teacher relationship;

Use of an academic program and method that meets the needs of each student or group;

Prior identification of misconceptions and background knowledge of students and taking measures [12].

An effective teacher organizes the relations within classroom, ensures the establishment and development of an order and acts as a counsellor as well as an effective teacher is the individual who is affected from the classroom climate. 
$\mathrm{He} / \mathrm{she}$ creates a class as a stage in the way that the attention of student would not go outside of the stage. A teacher sitting behind the teacher's table for the majority of time would allow the in-class conflicts and disputes [12].

[12] argues that for the provision of an effective classroom management, the teacher should have the following:

Content knowledge;

Professional knowledge;

General culture.

\begin{tabular}{llll}
\hline Improvement & \multicolumn{2}{c}{ Aimed knowledge and skills } & $\begin{array}{l}\text { Questions required to be } \\
\text { answered in classroom } \\
\text { management }\end{array}$ \\
\hline $\begin{array}{l}\text { Much bigger } \\
\text { scale }\end{array}$ & $\begin{array}{l}\text { Increase in the } \\
\text { amount of } \\
\text { information } \\
\text { (accumulation of } \\
\text { information) }\end{array}$ & $\begin{array}{l}\text { The information increase on } \\
\text { the basis of much bigger } \\
\text { improvement }\end{array}$ & $\begin{array}{l}\text { Where there is any } \\
\text { accumulated information, } \\
\text { "how to teach?" }\end{array}$ \\
$\begin{array}{ll}\text { Faster } \\
\text { Increase in } \\
\text { information diversity }\end{array}$ & $\begin{array}{l}\text { The information diversity } \\
\text { increase on the basis of faster } \\
\text { improvement }\end{array}$ & $\begin{array}{l}\text { Where there is various } \\
\text { information to teach, "which } \\
\text { to teach?" }\end{array}$ \\
& $\begin{array}{l}\text { Obsolescence in the } \\
\text { content of } \\
\text { information }\end{array}$ & $\begin{array}{l}\text { The content of information } \\
\text { that increased in amount and } \\
\text { diversity on the basis of } \\
\text { shorter improvement } \\
\text { becomes rapidly obsolescent. }\end{array}$ & $\begin{array}{l}\text { When the information that } \\
\text { increased in number and } \\
\text { diversity change in shorter } \\
\text { intervals, "why to teach" such } \\
\text { temporary information? }\end{array}$ \\
\hline
\end{tabular}

\section{Concept Cartoons}

The concept cartoons have designed and used by [13] for the first time. The word of cartoon is originated from "caricature" in French. According to the definition of [14] cartoon is "a comic picture telling all kinds of issues about people and society in an exaggerated way while leading to think". [15] explains cartoon as the most simple and drastic field for the "comprehension, interpretation and narration" efforts of art. A cartoon delivers an idea directly while shaking the thinking worlds of individuals. Teaching geometry with humour would enhance the interest of student into the lesson. Entertaining and interesting cartoons would make concentration easier for students. When the concept cartoons are related with the students and everyday life, the students would have more interest. Concept cartoons create a simple strategy route that engage students to the lessons and encourage more effective teaching, learning and evaluation in mathematics. The students may not relate the cartoons with the lesson before the lesson starts, however it is possible to bring an idea with posters [16].

Although concept cartoons look very simple in terms of their nature, some aspects should be taken into consideration during the preparation of cartoons. [17] listed such aspects as follows:

Limited number of texts, thus accessible by all age group learners regardless their limited illiteracy; 
Integration of scientific ideas with daily events, so that students can relate between scientific and daily circumstances;

Projected alternative ideas are based on common misunderstandings and researches defining misconceptions; therefore learners are ensured to see the majority of alternatives within the ideas as reliable;

Alternative ideas introduced with characters comprise scientifically accepted perspective/perspectives;

Ensuring to consider alternative ideas as all equal, yet preventing the learners to find out the correct alternative among issue.

According to [16], the general features of concept cartoons are as follows:

Ensuring the revealing of the existing knowledge and ideas of students;

Facilitating the elaboration of ideas through questioning and deepening;

Providing alternative perspectives;

Used as a stimulant to create a discussion platform;

Ensuring that the students question their own ideas;

Identifying misconceptions and indecisiveness and ensuring their elimination.

Leading to research;

Increase participation and motivation;

Possibility to use in assisting for summarising or revising a subject;

Concept cartoons enhance the attention of students towards the lesson and positively affect the misconceptions.

Aim and importance of research

The researcher prepared concept cartoons for enabling active learning in geometry lessons.

\section{Research issue}

The research issue was noted as what the opinions of students are on using concept cartoons during geometry lessons.

\section{Methodology}

The sampling of the study is comprised of $11 \mathrm{D}$ class students from 20 Temmuz Science High School located in Nicosia, Northern Cyprus for 2015-2016 academic year. Concept cartoons were prepared in accordance with the geometry subjects to be taught during a lesson that will cover 8 lesson hours (each lesson takes 40 minutes.). Trapezoid was chosen as the subject for concept cartoons. The features of trapezoid subject and students were included in the same cartoon.

\section{Research design}

For this study, interview, as a qualitative study, was used in order to indicate the opinions of students concerning the concept cartoons. According to [18], interview is "a process of mutual talk, which the participant is a part of, based on the questions on the research subject" [19]. Semi-structured interview technique was used during the interview. In such a technique, the researcher prepares the interview questions beforehand, however allows a partial-flexibility to the un- 
der-researched people during the interview so that the question can be re-arranged and discussed [20]. [20] points out the selection of people for interview, management of interview and recording of interview. Interview questions as one of the most used methods in qualitative researches, are comprised of issues that allows creating a reaction (attention) among students towards the cartoons [21].

\section{Data collection tool}

Control and experiment groups were established during the research. Concept cartoons that included the names of students from the experimental group were shown. The students were asked four open-ended questions. Before asking the prepared questions, the questions were discussed together with the teachers in the school, and were applied on a different student group in order to have content validity; consequently it was decided to ask 2 questions. The evaluation was performed after considering the answers of students given during the interview and frequency distribution.

The concept cartoons used in the classroom were given below:
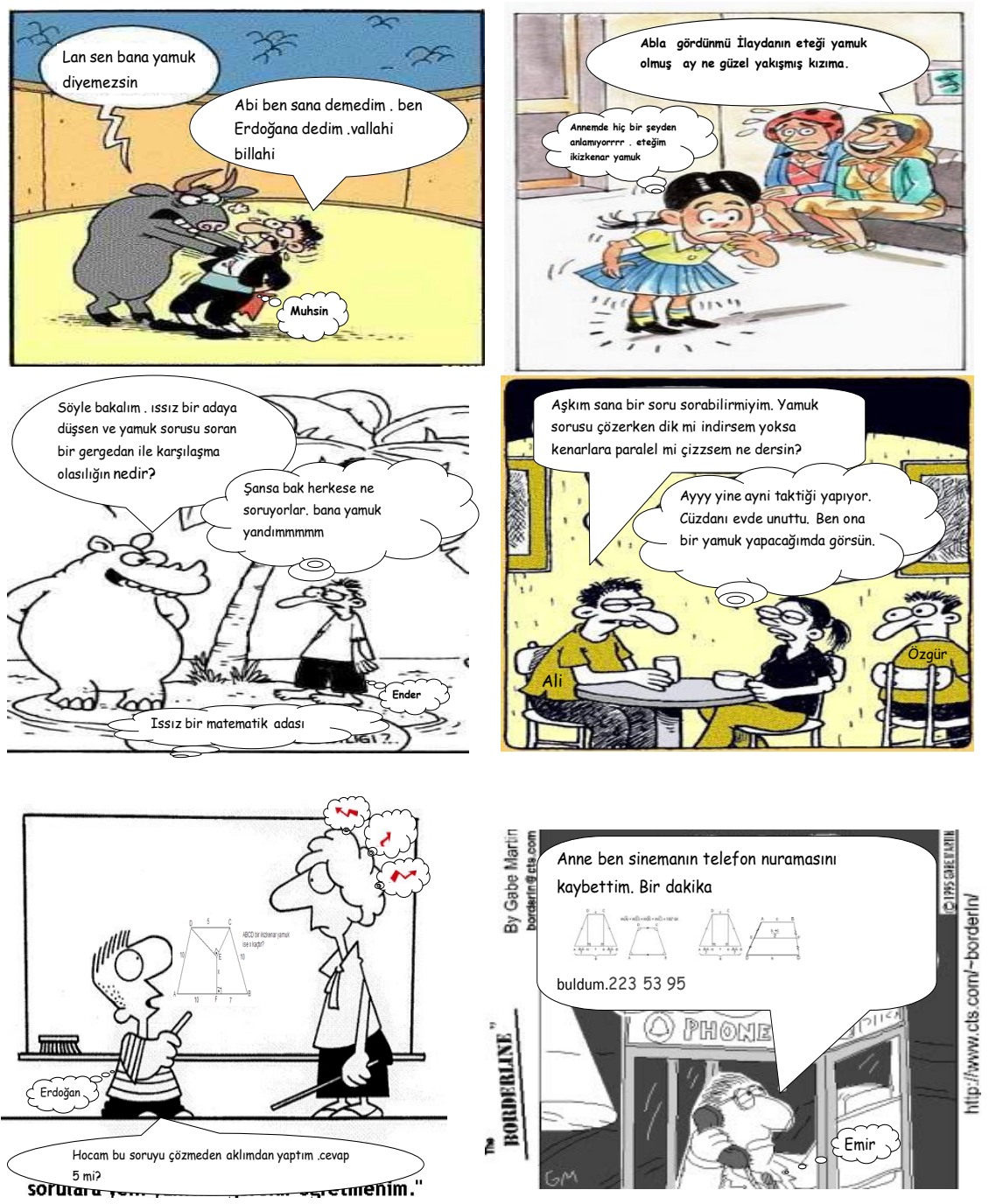

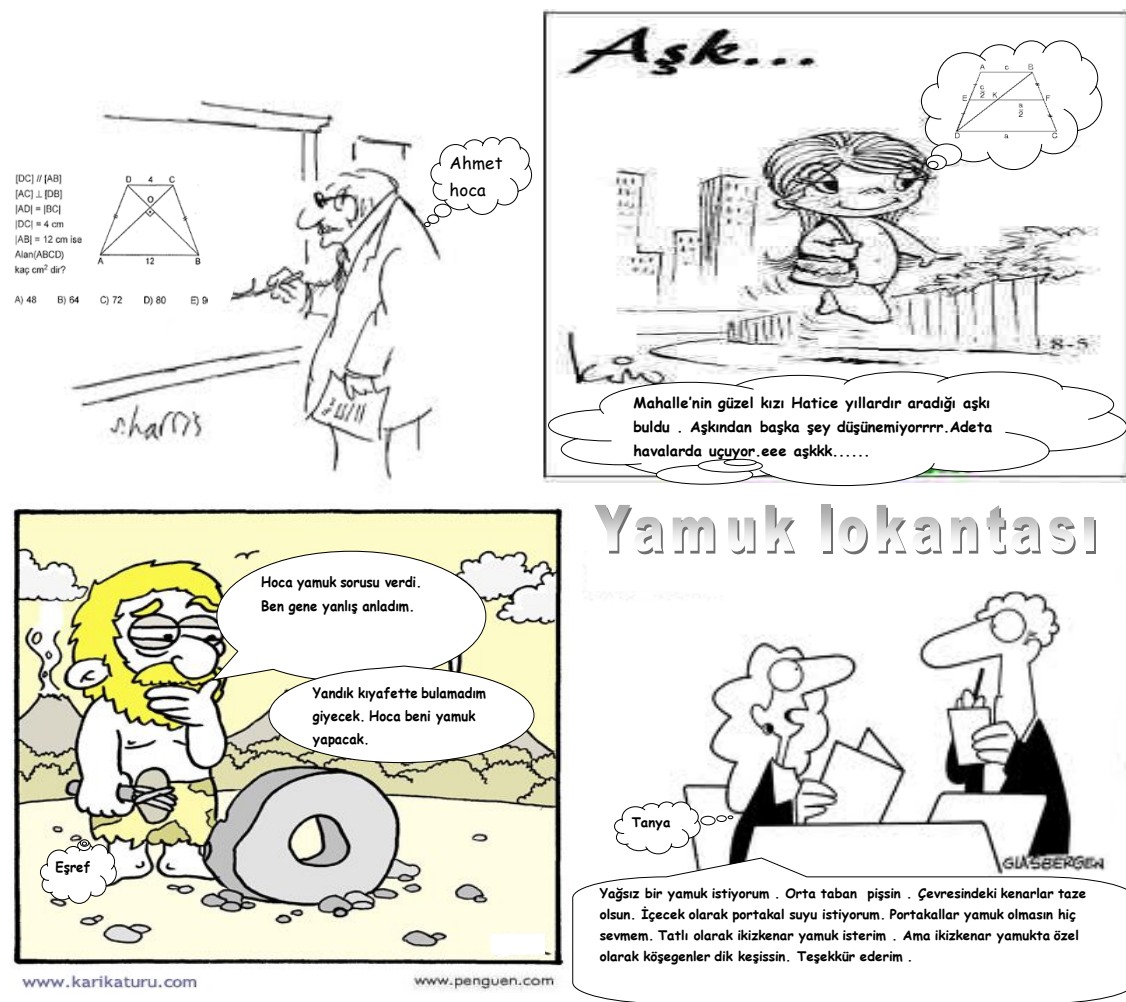

\section{Findings}

This part explains the answers and frequency distribution as shown in the table below for the experimental and control group.

\begin{tabular}{|c|c|c|c|c|c|}
\hline \multicolumn{6}{|c|}{ What was your reaction when you see the concept cartoons? } \\
\hline Experiment group ( 9 people) & $\mathrm{f}$ & & Control group ( 9 people) & & $\mathrm{f}$ \\
\hline $\begin{array}{l}\text { I saw the concept cartoons for the first } \\
\text { time }\end{array}$ & 9 & I sa & $\begin{array}{l}\text { he concept cartoons in the lesson fo } \\
\text { the first time }\end{array}$ & & 9 \\
\hline Cartoons were fun & 9 & & Cartoons were fun & & 9 \\
\hline It was interesting & 8 & & It was interesting & & 8 \\
\hline It was funny & 9 & & It was funny & & 8 \\
\hline I understood what it is after a close look & 9 & & erstood what it is after a close look & & 9 \\
\hline \multicolumn{6}{|c|}{ What are your opinions on the use of trapezoid in the concept cartoon? } \\
\hline Experimental group (9) & & f & Control group (9) & $\mathrm{f}$ & \\
\hline My interest for the lesson increased & & 9 & $\begin{array}{l}\text { My interest for the lesson } \\
\text { increased }\end{array}$ & 5 & \\
\hline $\begin{array}{l}\text { Being a part of cartoon arouse my } \\
\text { attention, which increased my interest } \\
\text { towards the lesson and cartoon }\end{array}$ & & 8 & $\begin{array}{l}\text { I wish to be part of the } \\
\text { cartoon }\end{array}$ & 8 & \\
\hline $\begin{array}{l}\text { I did not like the trapezoid subject but now } \\
\text { I have an interest }\end{array}$ & & 8 & $\begin{array}{l}\text { I am not good in geometry. } \\
\text { Nothing can change this }\end{array}$ & 8 & \\
\hline
\end{tabular}


The students in the experimental group, that their names were included in the cartoon, were observed to have an increase in their interest for the lesson. The students that had no interest in geometry lesson were felt as privileged and they started to study more.

The students in the control group were defined their introduction with the concept cartoon as interesting. However, since their names were not given in the cartoons, they continue to have no interest for the lesson.

\section{Discussion and Conclusion}

For an effective classroom management in geometry lesson, the learning should be structured on the basis of interests and perception styles of students, and by using daily events. Concept cartoon is frequently used in daily life; a visual based practice usually delivers the desired information and leads people into thinking. When students relate (Build Bridge) their everyday lives with the activities, the learning becomes permanent. Teachers may eliminate the misconceptions of students by making constant changes in the classroom management. When effectiveness gains continuity, the student will have sustained interest. Technical knowledge is required for the preparation of concept cartoons. Getting help from cartoonists would create more effective work during the preparation phase of concept cartoons. The existence of a traditional management and teachers predominantly in the schools would consider the new activity as meaningless and unnecessary.

\section{References}

[1] Aktaş, Y. (2002) Okulöncesi Dönemde Matematik Eğitimi. [Maths Education at Pre School Stage.] Nobel Tip kitapevi, Adana.

[2] Van Hiele, P.M. (1999) Developing Geometric Thinking through Activities that Begin with Play. Teaching Children Mathematics, 5-6, 310-317.

[3] Avc1, N. and Dere, H. (2002) Okulöncesi Çocuğu ve Matematik. V. Ulusal Fen Bilimleri ve Matematik Eğitimi Kongresi. [Pre School Child and Mathematics.]

[4] Spiegel, D. (1998) The Development of Geometric Knowledge. http://alumni.media.mit.edu/ spiegel/papers/Geometric_Knowledge.pdf

[5] Van De Walle, J.A. (2004) Elementary and Middle School Mathematics: Teaching Developmentally. 5th Edition, Printed in the United States of America.

[6] Baki, A. (2008) Kuramdan uygulamaya matematik eğitimi. [Math Education from Theory to Application.] Harf Eğitim Yayıncılıği, Ankara.

[7] MEBNET (2013) Ortaokul Matematik Dersi (5, 6, 7 ve 8. Sinıflar) Öğretim Programi. [Secondary School Math Education.] http://www.mebnet.net/

[8] Başar, H. (2006) Sinif yönetimi. [Classroom Management.] 13. Basim, Ani Yayincilik, Ankara.

[9] Erdoğan, I. (2001) Sınıf yönetimi: Ders, konferans, panel ve seminer etkinliklerinde başarinin yollari. [Classroom Management: Ways to Succeed in Lessons, Conferences, Panels and Seminars.] 3. Basım, Sistem Yayincilik, Istanbul.

[10] Jones, V.F. (1996) Classroom Management. In: Silula, J., Ed., Handbook of Research on Teacher Education, Macmillan, New York, 503-521. 
[11] Weinstein, C.S. (1996) Secondary Classroom Management: Lessons from Research and Practice. McGraw-Hill, New York.

[12] Boyacı (2006) Yapilandirmaci Sinif Yönetimi. [Constructivist Classroom Management.]

[13] Naylor, S. and McMurdo, A. (1990) Supporting Science in Schools. Timperley. Nussbaum.

[14] Turkish Language Association (2016). http://www.tdk.gov.tr

[15] Şahin, F. (2002) Kavram haritalarının değerlendirme aracı olarak kullanilmasi ile ilgili bir araştirma. [A Research on the Use of Concept Maps as an Evaluation Tool.] Pamukkale Üniversitesi Ĕ̈itim Fakültesi Dergisi, 1, 17-32.

[16] Dabell, J. (2008) Using Concept Cartoons. Mathematics Teaching Incorporating Micromath, 209, 34-36.

[17] Keogh, B. and Naylor, S. (1999) Concept Cartoons, Teaching and Learning in Science: An Evaluation. International Journal of Science Education, 21, 431-446. https://doi.org/10.1080/095006999290642

[18] DeMarrris, K. (2004) Qualitative Interview Studies: Learning through Experience. Mahwah, Erlbaum.

[19] Merriam, S.B. (2013) Qualitative Research: A Guide to Design and Implementation. John Wiley \& Sons Inc., New York.

[20] Karasar, N. (2005) Bilimsel Araştirma Yöntemleri. [Scientific Research Methods.] 15 Baski, Nobel Yayin, Ankara.

[21] Kıncal, R.Y. (2013) Bilimsel Araştirma Yöntemi. [Scientific Research Methods.] 2 Basim, Nobel Yayin, Ankara.

Submit or recommend next manuscript to OALib Journal and we will provide best service for you:

- Publication frequency: Monthly

- 9 subject areas of science, technology and medicine

- Fair and rigorous peer-review system

- Fast publication process

- Article promotion in various social networking sites (LinkedIn, Facebook, Twitter, etc.)

- Maximum dissemination of your research work

Submit Your Paper Online: Click Here to Submit

Or Contact service@oalib.com 